\title{
The Mystery of a Cochlear Amplifier
}

\author{
Chul-Hee Choi \\ Department of Audiology and Speech-Language Pathology, Research Institute of Biomimetic Sensory Control, and \\ Catholic Hearing Voice Speech Center, Catholic University of Daegu, Gyeongsan, Korea
}

\author{
와우증폭기의 비밀 \\ 최 철 희 \\ 대구가톨릭대학교 바이오메디대학 언어청각치료학과, 생체모방감각제어연구소, 가톨릭 청각음성언어센터
}

\begin{abstract}
The presence of a cochlear amplifier is required for a dramatic improvement of hearing sensitivity and frequency selectivity in normal hearing of mammals. The cochlear amplifier refers to the active process of the cochlea maximizing the gain in response to low levels of input signals and minimizing the gain at their high levels as an automatic gain control. The cochlear amplifier is involved in two gain or transfer functions of hair cells or outer hair cells in the cochlea: mechano-electrical transduction (MET) and electro-mechanical transduction (EMT). The mechano-eletcrical transduction located within the stereocilia on the apex of the OHCs indicates a nonlinear transducer function opening the transducer channels through deflection of hair cell bundle into the tallest stereocilia and entering the $\mathrm{K}+$ and $\mathrm{Ca}^{2+}$ into the cells which increases the hair cell receptor potentials, called depolarization and closing the channels through the deflection in the opposite direction and outflowing the $\mathrm{K}^{+}$and $\mathrm{Ca}^{2+}$ out of the cells which decreases the hair cell receptor potentials, called hyperpolarization. The electro-mechanical transduction placed in the lateral wall of the OHCs represents the changes in the length and form of isolated $\mathrm{OHC}$ in response to the changes of $\mathrm{OHC}$ receptor potentials in mammals. This paper reviews the basic mechanisms and the new discovery of the cochlear amplifier, the new methods to characterize the presence, and the clinical approaches to expose the mystery.
\end{abstract}

Key Words: Cochlear amplifier, Mechano-eletcrical transduction, Electro-mechanical transduction, Electromotility, Outer hair cell.

Received: Marcn 2, 2016 / Accepted: March 10, 2016

Correspondence: Chul-Hee Choi, Department of Audiology \& Speech-Language Pathology, Research Institute of Biomimetic Sensory Control, and Catholic Hearing Voice Speech Center, Catholic University of Daegu, 13-13 Hayang-ro, Hayang-up, Gyeongsan 38430, Korea

Tel: +82-53-850-2541 / Fax: +82-53-359-0780 / E-mail: cchoi@cu.ac.kr

\section{INTRODUCTION}

동물의 몸 기관에서 청각기관은 내이(inner ear)에 있는 와 우(cochlea)이다. 귀로 들어오는 음향학적인 신호는 중이(middle ear)에서 기계적인 신호로 전환되고 와우에서 다시 전기신 호로 전환되어 뇌로 전달된다. 이러한 청각의 신호전달체계에 서 와우는 능동적으로 작은 입력신호를 크게 증폭시키고 큰 강도의 신호는 증폭을 줄이거나 증폭하지 않는 자동이득조절 기(automatic gain control)처럼 기능한다. 이것을 와우증폭기 (cochlear amplifier)라고 한다. 와우증폭기는 정상 청각에 있 어 청각 민감성(hearing sensitivity)과 주파수 분해능력(frequency resolution)의 극적인 개선과 역동범위(dynamic range) 의 광범위한 확대를 위해 반드시 필요한 것으로 알려지고 있다. 오래 전부터 와우증폭기의 존재는 인정되어 왔지만 그것의 구
체적인 메커니즘과 위치는 청각학 분야에서 논쟁의 중심이 되 어 왔다. 특히 와우증폭기의 근원에 대한 의문은 청각학의 학 문적인 발전과 더불어 조금씩 그 비밀이 밝혀지고 있지만 그것 에 대한 완전한 이해는 아직까지 소원하다. 본 논문은 청각학 의 발전과 더불어 밝혀진 와우증폭기에 대한 비밀을 관련 연구 결과들을 토대로 기술하고자 한다. 따라서 본 논문은 청상청각 에서 와우증폭기의 역할과 기능에 대한 분명한 이해와 더불어 앞으로 해결되어야 할 관련 연구문제에 대한 중요한 실마리를 제공할 것이다.

\section{COCHLEAR AMPLIFIER}

와우 증폭기의 존재에 대한 필요는 Gold(1948)에 의해 처음 으로 제기되었다. 낮은 소리의 강도에도 민감하게 반응하는 와 
우의 특성 때문에 와우 증폭기의 존재가 필요할 수도 있다는 것을 제시하였지만 와우의 기저막(basilar membrane)에 대한 분석에 흥미를 가진 당시의 연구자들은 Gold의 주장에 관심을 기울이지 않았다. 기저막에 대한 관심은 중이소골의 등골(stapes)의 움직임과 와우 기저막의 움직임이 밀접하게 상관되기 때문이다. 즉, 귀에 들려오는 음향학적 신호는 중이에서 기계적 인 신호로 전환되고 내이의 와우에서 전기신호로 전환되는데 이 때 중이소골의 등골의 움직임과 와우의 코르티 기관(organ of Corti)의 기저막의 움직임은 서로 밀접하게 상관되어 있다. 와우의 기저막은 기저부(base)와 첨단부(apex)로 나뉘는데 기 저막은 폭이 짧고 두껍고 뻣뻣한 반면에 첨단부는 폭이 넓고 얇 고 탄력이 있어 길이에 따라 강성도(stiffness)가 다른 생리학적 특성을 가지고 있다. 공학분야의 발전의 도움으로 당시의 청각 연구자들은 소리에 대한 와우 기저막(basilar membrane)의 기 계적인 반응의 특성을 밝히고자 하였다. 대표적으로 Bekesy (1960)는 레이저 간섭계(laser interferometry)를 사용하여 와 우의 기적막이 와우에서의 위치에 따라 특정주파수에 최대 변 위(maximal displacement)를 보인다는 진행파 이론(traveling wave theory)을 제시하였다. 기저막의 위치에 따른 강성도의 차이에 의해 기저막의 최대 변위가 결정되는데 음향학적 소리 에 반응하여 기저막의 변위는 기저부에서 첨단부로 진행되고 올라갈수록 변위의 양은 점차 증가하다가 특정 위치에서 그 절 정을 보이고 그 후 빠르게 쇠퇴하는 특성을 보인다(Gelfand, 1997). 기적막의 최대 움직임(peak)의 위치는 입력되는 소리의 주파수에 의해 결정되는데 고주파수 자극은 기저막의 기저부 에서 최대 진폭을 보이는 반면 저주파수 자극은 기저막의 첨단 부에서 최대 진폭을 보인다. Bekesy의 진행파 이론은 기저막의 위치와 주파수와의 상관관계를 나타내기 때문에 청각의 위치 (place) 이론 또는 음위상 조직(tonotopic organization)으로 불 린다(Clark, 2008). 그러나 Bekesy의 이론은 죽은 동물이나 사 람의 와우의 반응을 분석하였으므로 음향학적인 입력자극에 대한 기저막의 반응은 선형적(linear)이고 수동적인(passive) 것 으로 가정되었다. 새롭게 발전된 뫼스바우어 측정기술(Mossbauer technique)을 사용하여 살아있는 다람쥐 원숭이 와우의 기저막을 측정한 결과, 주파수에 따른 이소골의 추골(malleus) 의 변위에 대한 기저막의 변위의 진폭율(dB)은 비선형적(nonlinear)이고 능동적인(active) 것으로 판명되었다(Johnstone \& Boyle, 1967; Rhode, 1971; Clark, 2008). 민감한 레이저 속도 측증계(laser velocimetry)를 사용하여 살아있는 친칠라의 와 우를 측정한 결과 기저막과 청각신경섬유의 주파수 조율(frequency tuning)은 약한 강도인 $0 \mathrm{~dB}$ SPL 자극에서 약 $50 \mathrm{~dB}$ 의 이득을 보여주었다(Ruggero et al., 2000). 위의 연구결과로 나타난 이득의 양인 $50 \mathrm{~dB}$ 가 와우 기저막의 수동적인 과정과
능동적인 과정의 차이, 즉 와우 증폭기의 크기인 셈이다.

\section{STEREOCILIARY MOVEMENT OF HAIR CELL}

와우의 기능에 대한 분석은 와우의 변환함수(transduction function)를 특성화하려는 다양한 연구에 의해 수행되어져 왔 다. 청각기관인 와우 내 코르티 기관은 와우의 중간에 위치한 중간계(scala media) 또는 와우관(cochlear duct)에 위치해 있 고 아래로는 기저막과 위로는 개막(tectorial membrane) 사이 에 위치해 있다. 와우의 코르티 기관에는 유모세포(hair cells) 가 있는데 와우축(modiolus)을 중심으로 안에 위치한 세포를 내유모세포(inner hair cells)이라 하고 바깥에 있는 세포를 외 유모세포(outer hair cells)라 한다. 형태적으로 내유모세포는 플라스크 모양으로 한 줄로 배열되어 있고 섬모(stereocilia)는 -자 모양으로 부호화(coding)의 역할, 즉 감각자극을 뇌로 전 달하는 역할을 수행한다(Choi, 2010, 2015; Clark 2008). 외유 모세포는 실린더 모양으로 셋 또는 네 줄로 배열되어 있고 섬모 는 v 또는 $\mathrm{w}$ 자 모양으로 증폭의 역할을 하며 뇌에서 와우까지 청각정보가 전달된다(Choi, 2010, 2015; Clark 2008). 와우의 유모세포는 와우의 나노구조에서 핵심적인 기관으로 많은 연 구의 주대상이 되어 왔는데 그 이유는 와우의 내유모세포와 외유모세포의 위에 있는 섬모다발(stereociliary bundle)의 운 동이 유모세포의 이온의 흐름과 전기흥분을 유발하기 때문이 다(Ohlemiller, 2008). 유모세포는 망상층(reticular lamina)을 중심으로 위의 섬모다발과 아래의 세포체(cell body)로 구분되 는데 위의 섬모다발은 큰 섬모에서 작은 섬모까지 끝링크(tip link)로 나란히 배열되어 있다. 와우의 코르티 기관이 위치한 중 간계(scala media)는 다량의 칼륨이온 $\left(\mathrm{K}^{+}\right)$과 소량의 나트륨이 온 $\left(\mathrm{Na}^{+}\right)$을 포함하고 있다. 귀에 음향 신호가 들어와 고막을 안 쪽으로 밀면 그 힘이 이소골에 전달되어 와우의 내림프(endolymph)를 밀면서 와우 기저막을 위로 움직이게 하면 유모세포 의 섬모다발이 와우축으로부터 멀리 위치한 가장 긴 섬모 쪽으 로 움직이고 이 때 끝링크의 문이 열려 중간계의 칼륨이온이 유모 안으로 들어가게 된다. 이렇게 섬모의 채널이 열리는 것을 탈분극(depolarization)이라고 하며 탈분극이 되면 유모세포 막에는 수용기 전위(receptor potentials)가 생성된다. 반대로 고막이 바깥 쪽으로 끌어당기면 이소골과 내림프를 밖으로 끌 어당기고 섬모는 가장 작은 쪽으로 움직이면서 끝링크의 문이 닫히게 된다. 이것을 과분극(hyperpolarization)이라고 하며 과 분극이 될 때 유모세포 막에는 수용기 전위가 생성되지 않고 감소한다(Choi, 2010, 2014; Ohlemiller, 2008). 이러한 섬모의 움직임에 의해 세포 막전위의 변화의 특성을 분석하면 와우의 
변환함수를 얻을 수 있다.

와우의 변환함수의 특성을 분석하는 연구는 하나의 유모세 포의 막전위(hair cell membrane potential)를 사용할 수도 있 고 전체 와우전위(gross cochlear potential)를 사용할 수도 있 다. 세포의 막전위를 사용한 연구들은 1970년대에 널리 사용된 조각집계법(patch-clamp technique)을 사용하여 내유모세포 와 외유모세포 내 교류(alternating current, $\mathrm{AC}$ )와 직류(direct current, DC)의 전기반응을 분석하여 와우의 변환함수를 밝히 고자 하였다(Russell \& Sellick, 1978; Hudspeth \& Jacobs, 1979; Dallos et al., 1982). 이 연구들로 와우 변환함수는 압축 적인 비선형성(compressive nonlinearity)과 비대칭성(asymmetry)의 특성을 가지는 것으로 드러났다. 즉 약한 전기자극 보다는 강한 전기자극에는 세포막 전압(voltage)은 비선형적인 압축을 보였고 자극이 없는 휴지전위(resting potential)에서 탈 분극까지의 세포막 전압의 크기와 휴지전위에서 과분극까지의 크기가 비대칭적으로 서로 일치하지 않았다. 특히 비대칭성에 있어서 과분극 방향의 세포막 전압의 변화가 탈분극 방향의 것 보다 더 컸다(Cody \& Russell, 1987). 와우의 전체 전위를 사용 하는 연구들은 정원창(round window)에 놓인 활동전극(active electrode)을 사용하여 와우전위(cochlear microphonic)와 가 중전압(summating potential)과 같은 전기반응을 얻었다. 와우 전위(cochlear microphonic)는 와우의 기저부의 공간적인 가 중치(spatial summation)에 의해 생성되는 원거리 교류 전위 (far-field AC potential)로 백색소음(white noise)와 순음과 같 은 자극에 의해 생성되며 와우가 마이크처럼 소리를 증폭한다 는 의미에서 와우 마이크로폰이라 불리며 주로 외유모세포에 서 생성된다. 가중전압(summating potential)은 유모세포에서 생성되는 직류전위(DC potential)로 주로 내유모세포에서 생성 되었다(Choi et al., 2002, 2004, 2014). 와우전위와 가중전압을 통해 와우 변환함수를 도출하는 또 다른 방법은 저주파수 변 조음(low frequency modulated bias tone)을 사용하는 것이다. 저주파수 변조음의 사용은 와우관이 전정계(scala vestibule) 와 고실계(scala tympani) 방향으로 움직일 때 와우의 변환함 수를 도출하게 하는 유용한 방법이다. 와우전위는 와우의 변환 함수의 제 1 차 미분 함수와 비례하지만(Choi, 2010; Choi et al., 2010) 가중전압은 와우의 변환함수의 제 2 차 미분 함수와 비례 하였다(Choi et al, 2004). 게다가 저주파수 변조음을 사용하여 와우의 변환함수 제 3 차 미분함수와 변조이음향방사(distortion product otoacoustic emission)의 비례관계를 토대로 변조이음 향방사로부터 와우의 변환함수를 도출하였다(Bian et al., 2002; Bian, 2004).

\section{OUTER HAIR CELL ELECTROMOTILITY}

유모세포의 막전위는 유모세포의 섬모운동의 결과이지만 유 모세포의 전기반응은 또 다른 기계적 반응, 즉 세포의 길이변 화를 유도한다는 사실이 Brownell(1985)에 의해 처음으로 보 고되었다. 이러한 유모세포의 길이변화는 오직 외유모세포에서 만 관찰되었다. 외유모세포의 수용체 전위가 생성되면 외유모 세포의 길이는 짧아지고 측면벽은 두꺼워지는 반면에 수용체 전위가 감소하면 외유모세포의 길이는 길어지고 측면벽은 엷어 졌다. 게다가 외유모세포의 길이의 변화는 다시 와우 기저막의 움직임에 영향을 미친다. 즉 외유모세포의 수용기 전위가 생성 되면 외유모세포의 측면벽에서 힘이 생성되어 외유모세포의 길 이가 줄어들고 이것은 다시 기저막을 위로 끌어 당기는 반면 수용기 전위가 감소되면 외유모세포의 측면벽에서 힘이 줄어 들어 외유모세포의 길이가 길어져 기저막을 아래로 밀게 된다 (Choi, 2010, 2011). 외유모세포의 이러한 특징을 외유모세포의 전기운동성(electromotility) 또는 전기기계적 변환(electromechanical transduction)이라고 한다. 외유모세포의 전기운동 성은 외부의 자극이 없이 외이도에서 측정할 수 있는 작은 강 도의 신호인 자발이음향방사(spontaneous ototacoustic emission)의 원인이 된다(Brownell, 1990).

외유모세포의 전기운동성은 외유모세포의 측면벽에서 만들 어 지며 그 이유는 외유모세포 내의 팽창압력(turgor pressure) 을 가지고 있는 독특한 구조 때문이다. 외유모세포 구조는 엑 틴(actin), 스펙트린(spectrin), 및 기둥(pillar)으로 구성된 비수 조 공간(extracisternal space)이 중간의 세포골격(cytoskeleton)에 형성하고 측면벽은 원형질막(plasma membrane), 피질 격자(cortical lattice), 그리고 표면하수조(subsurface cisternae) 의 피부하층 구조를 형성하는데(Choi, 2014) 원형질막 위에는 외유모세포의 전기적 운동을 책임지는 단백질인 프레스틴 (prestin)이 존재한다고 밝혀졌다(Zheng et al., 2000). 프레스틴 은 아미노-중탄산염수송체(anino-bicarbonate transporters) 의 일원으로 약 10 12개의 막관통(transmembrane)으로 구성 되어 있고 내재단백질(integral membrane protein)의 상과(superfamily) SLC26의 A5로서 아미노산 순서(sequence)의 황산 염변형소재(sulfate transport motif)를 가지고 있다(Dallos et al., 2006). 프레스틴이 유전적으로 결핍될 경우 약 $40 ~ 60 \mathrm{~dB}$ 의 청각상실을 가진다는 사실은 정상청각의 와우증폭에 프레스틴 은 반드시 필요하다는 것을 의미한다(Liberman et al., 2002). Iwasa(2010)에 따르면 프레스틴의 기능은 완벽하게 알려져 있 지는 않지만 일반적으로 외유모세포의 수용기 전위의 변화를 감지할 수 있는 전압센서(voltage sensor)로서의 기능을 수행할 뿐만 아니라 외유모세포의 형태변화를 진행하고 탈분극(depo- 
larization)과 과분극(hyperpolarization)에 반응하여 외유모세 포의 길이변화를 용이하게 하는 작동기(actuator)의 기능을 수 행한다고 한다.

\section{CONCLUSIONS}

와우 증폭기의 존재는 정상청각의 청각 민감성, 주파수 분해 능력, 및 역동적인 범위의 극적인 개선에 반드시 필요하다. 와 우 증폭기의 필요성은 오래 전부터 주장되어 왔지만 그 실체는 청각학의 학문적인 발전과 더불어 조금씩 밝혀졌다. 와우 증폭 기의 기본적인 메커니즘은 와우의 유모세포의 위에 존재하는 섬모운동으로 드러난 와우의 기계-전기적인 변환과정과 외유 모세포의 전기운동성으로 불리는 전기-기계적인 변환과정이 다. 이 두 과정들에 대한 과학적인 증거는 지속적으로 수집되 고 있지만 완전한 이해를 위해서는 여전히 많은 연구들이 필요 하다. 와우 증폭기의 기본 매카니즘에 대한 와우의 병리생리학 적 접근은 와우의 손상부위에 대한 변별과 차별을 가능하게 하며 종에 따른 와우 증폭기의 다양한 차이도 밝혀질 것으로 보인다. 특히 관련된 다른 분야와 새로운 공학의 발전은 와우 증폭기에 대한 신비를 밝히는데 공헌할 것이다.

중심 단어 : 와우증폭기·기계-전기적 변환·전기-기계적 변환 · 전기적 운동·외유모세포.

\section{Acknowledgments}

This research was supported by Basic Science Research Program through the National Research Foundation of Korea (NRF) funded by the Ministry of Education (2012R1A1A4A01017139).

\section{REFERENCES}

Bekesy, G. (1960). Experiments in Hearing. New York, NY: McGraw-Hill. Bian, L. (2004). Cochlear compression: effects of low-frequency biasing on quadratic distortion product otoacoustic emissions. Journal of the Acoustical Society of America, 116, 3559-3571.

Bian, L., Chertoff, M. E., \& Miller, E. (2002). Deriving a cochlear transducer function from low-frequency modulation of distortion product otoacoustic emissions. Journal of the Acoustical Society of America, 112, 198-210.

Brownell, W. E. (1990). Outer hair cell electromotility and otoacoustic emissions. Ear \& Hearing, 11, 82-92.

Brownell, W. E., Bader, C. R., Bertrand, D., \& De Ribaupierre, Y. (1985). Evoked mechanical responses of isolated cochlear outer hair cells. Science, 227, 194-196.

Choi, C. H. (2010). Mechanisms of Active Process and Amplification in
Cochlea. Korean Journal of Audiology, 14, 81-87.

Choi, C. H. (2011). Prestin and Motility of the Cochlear Outer Hair Cell. Korean Journal of Audiology, 15, 101-106.

Choi, C. H. (2014). Anatomy \& Physiology of Hearing Organ. In G. S. Kim et al. Introduction to Audiology (pp. 27-52). Seoul, Korea: Hakjisa.

Choi, C. H., Bian, L., \& Chertoff, M. E. (2010). Deriving a cochlear transducer function from low frequency modulated cochlear microphonic. Korean Journal of Communication Disorders, 15(2), 232-250.

Choi, C. H., Chertoff, M. E., Bian, L., \& Lerner D. (2004). Constructing a cochlear transducer function from the summating potential using a low-frequency bias tone. Journal of the Acoustical Society of America, 116, 2996-3007.

Choi, C. H., Chertoff, M. E., \& Yi, X. (2002). Characterizing cochlear mechano-electric transduction with a nonlinear system identification technique: The influence of the middle ear. Journal of the Acoustical Society of America, 112, 2898-2909.

Clark, W. W. (2008). Macromechanics: Basilar Membrane Responses. In W. W. Clark \& K. K. Ohlemiller. Anatomy and Physiology of Hearing For Audiologists (pp. 123-136). New York, NY:Thomson Delmar Learning.

Cody, A. R. \& Russell, I. J. (1987). The response of hair cells in the basal turn of guinea pig cochlea to tones. Journal of Physiology, 383, 551-569.

Dallos, P., Santos-Sacchi, J., \& Flock, A. (1982). Intracellular recordings from cochlear outer hair cells. Science, 218, 582-584.

Dallos. P., Zheng, J., \& Cheatham, M. A. (2006). Prestin and the cochlear amplifier. Journal of Physiology, 576, 37-42.

Gelfand, S. A. (1997). Essentials of Audiology. New York, NY: Thieme.

Gold, T. (1948). Hearing II. The physical basis of the action of the cochlea. Proceedings of the Royal Society of London B, 135, 492-498.

Hudspeth, A. J. \& Jacobs, R. (1979). Stereocilia mediate transduction in vertebrate hair cells. Proceedings of the National Academy of Sciences, 76, 1506-09.

Iwasa, K. H. (2010). Electromotility of outer hair cells. In P. A. Fuchs (Ed.), The Oxford Handbook of Auditory Science: The Ear (pp.179-212). New York, NY: Oxford University Press.

Johnstone, B. M. \& Boyle, A. J. E. (1967). Basilar membrane vibration examined with the Mossbauer technique. Science, 158, 390-391.

Liberman, M. C., Gao, J., He, D. Z., Wu, X., Jia, S., \& Zuo, J. (2002). Prestin is required for electromotility of the outer hair cell and for the cochlear amplifier. Nature, 419, 300-304.

Ohlemiller, K. K. (2008). Micromechanics: Transduction and Hair Cell Function. In W. W. Clark \& K. K.Ohlemiller. Anatomy and Physiology of Hearing For Audiologists (pp. 137-162). New York, NY: Thomson Delmar Learning.

Rhode, W. S. (1971). Observation of the vibration of the basilar membrane in squirrel monkeys using the Mossbauer technique. Journal of the Acoustical Society of America, 49, 1218-1231.

Ruggero, M., Narayan, S. S., Temchin, A. N., \& Recio, A. (2000). Mechanical bases of frequency tuning and neural excitation at the base of the cochlea: Comparison of basilar-membrane vibration and auditorynerve-fiber response in chinchilla. Proceedings of the National Academy of Sciences, 97, 11744-11750.

Russell, I. J. \& Sellick, P. M. (1978).Intracellular studies of hair cells in the mammalian cochlea. Journal of Physiology, 284, 261-289.

Zheng, J., Shen, W., He, D. Z., Long, K. B., Madison, L. D., \& Dallos, P. (2000). Prestin is the motor protein of cochlear outer hair cells. Nature, $405,149-155$ 